\title{
The Applicability of Mediation as an Alternative Dispute Resolution Mechanism under OHADA Law
}

\author{
Kifemmabuh Antonia Leinyuy*
}

Ph.D Research Candidate, Faculty of Law and Political Science, University of Dschang, Dschang, Cameroon

DOI: $10.36348 /$ sijlcj.2020.v03i04.005

| Received: 11.03.2020 | Accepted: 24.03.2020 | Published: 11.04 .2020

*Corresponding author: Kifemmabuh Antonia Leinyuy

\section{Abstract}

Almost 20 years after it adopted the Uniform Act on Arbitration, OHADA revised its Uniform Act on Arbitration and adopted a new Uniform Act on Mediation along with the fresh set of arbitration rules of the Common Court of Justice and Arbitration in Abidjan. These three texts were revised with the assistance of consultants. Among other changes, with the 2018 Uniform Act on Mediation, a solid platform for the use of mediation in the region is now in place. The ability of mediators to carry out their adjudication function with judicial intervention remains a major challenge by parties under the OHADA zones. In this light, the worry which this article seeks to uncover is how the new mediation law is applicable and facilitates the amicable settlement of investment disputes. The article also highlights the legal basis regulating the mediation process as a whole. In attaining these objectives, we employ doctrinal research methodology. The article conclude with vigorous recommendations which if effectively implemented will go a long way to enhance business (investment) security.

Keywords: Applicability, Mediation, Alternative, Dispute, Resolution, Mechanism, OHADA Uniform Act.

Copyright @ 2020: This is an open-access article distributed under the terms of the Creative Commons Attribution license which permits unrestricted use, distribution, and reproduction in any medium for non-commercial use (NonCommercial, or CC-BY-NC) provided the original author and source are credited.

\section{INTRODUCTION}

The OHADA Council of Ministers adopted on the $23^{\text {rd }}$ and $24^{\text {th }}$ November 2017, three major texts; a Uniform Act on Mediation, Uniform Act on Arbitration and revised rules of arbitration of the Common Court of Justice and Arbitration. Over the past few years, Africa has become a center of exponential economic growth with large projects emerging all over the continent in the energy, natural resources, and banking and telecommunication sectors. In this context, 17 West and Central African countries created OHADA in 1993, whose aim is to streamline the legal environment of corporations, better secure economic activities and stimulate foreign investment [1]. According to a study published by Afro barometer in March 2017, after a survey of 53,935 people from 36 African countries, $43 \%$ of respondents do not trust the justice system, $33 \%$ believe that judges are corrupt and only $13 \%$ have settled their litigation in court in the last 5 years [2]. The results of this study confirm the unfavourable conditions of access to justice (expensive legal fees, lack of access to a lawyer or legal texts) which can also be explained by the rule of the so-called "traditional" amicable settlements that are less expensive [3]. There still exists the amicable settlement of disputes under the palaver tree; protagonists debating before a jury formed by the population and the judge whose role is often entrusted to a traditional authority.

As a preliminary note, it is worth recalling that mediation as a new Alternative Dispute Resolution is different from arbitration. Arbitration is a private justice by which the parties appoint one or more arbitrators to settle their dispute; the arbitrator deciding in accordance with the principles of law. His role is similar to that of a State judge in the sense that the award made by him is res judicata and his solution is binding upon the parties. Mediation on the other hand, is an informal procedure facilitated by a mediator whose function is to assist the parties to negotiate in the dispute between them, in order to reach an agreement. He makes no decision and the parties are not bound by the proposals made by him during the negotiation.

In a nutshell, the main difference between arbitration and mediation lies in the fact that arbitration leads to a writ of execution in the form of an arbitral award, whereas mediation leads to an agreement between the parties which do not constitute the writ of execution. The execution of the mediation agreement is, therefore, left to the discretion of the parties; the latter can appeal 
to the judge to request the opposition of the executory formula on the agreement [4].

\section{UNDERSTANDING THE NOTION OF MEDIATION}

Article 1 of the Uniform Act on Mediation broadly defines mediation as "any process, whatever its name, in which the parties request a third party to help them reach an amicable settlement in regard to a dispute, conflicting relationships, involving natural or legal persons, including public entities or the State. This clear definition of mediation distinguishes it from other related notions. The word third party in this definition refers to the mediator who is asked to mediate [5].

The notions that are close and can be confused with the notion of mediation are numerous. For instance, we have negotiation which is a process of discussion between parties in order to reach an agreement on a matter. The negotiator is different from the mediator in the sense that he is a party to the negotiation; meanwhile the mediator is an impartial and neutral party to the mediation. We also have conciliation that differs from mediation in the sense that mediation requires the intervention of a third party that intervenes more actively in the search for a solution to the dispute.

According to Prof Henri Touzard [6], while the conciliator merely facilitates relations and communications between the parties, the mediator may intervene in the discussion, make suggestions and proposals or even make recommendations in order to reach an agreement. However, as in the context of conciliation, the third party mediator is only a catalyst in the search for a solution to the conflict between the parties. He has no power to settle disputes or impose a solution on parties. Andre Jean Arnaud [7] perfectly summarized these two distinctive elements when he said that mediation is only a form of conciliation and that the mediator is only a particularly active conciliator.

\section{Modes of mediation under ohada law}

Mediation takes two different forms under the Uniform Act on Mediation; Judicial mediation and conventional mediation [8]. Judicial mediation is that which occurs at the request or invitation of the State Court. In case the Uniform Act on Mediation does not specify jurisdictional criteria of the State Court, there is every reason to believe that all the jurisdictions of the OHADA Member States would be to invite the parties to a dispute to implement the mediation. Conventional Mediation on the other hand is one which is implemented directly by the parties.

Also, mediation could either be ad hoc or institutional. The absence of codification did not favour the popularization of mediation in the sense that, in order to make use of it, it was mandatory to be attached to a mediation center with rules which could serve as a road map for the conduct of the procedure [9]. Certain mediation centers that existed already include; the Arbitration, Mediation and Conciliation Center of Benin, the National Center for Arbitration, Conciliation and Mediation of Democratic Republic of Congo and the Ouagadougou Arbitration, Mediation and Conciliation Centre (CAMC-O). The parties did not have the opportunity to conduct their mediation on an ad hoc basis, meaning outside of any mediation center.

The adoption of the Uniform Act on Mediation by the OHADA Legislator fills the gab since this new act allows parties who do not want to be attached to a Mediation Center, to be able to conduct their mediation in accordance with the provisions of the Uniform Act on Mediation (ad hoc arbitration). The parties have the possibility to determine themselves the modalities of the mediation and in particular, the course of proceedings, its duration, the related expenses and the delimitation of the intervention of the mediator. Thus, we can only welcome the initiative of the OHADA Legislator who by codifying mediation has allowed investors to have a more flexible Alternative Dispute Resolution Mechanism than arbitration, and contribute to the attractiveness of the OHADA Zone [10].

\section{The scope of application of mediation under ohada law}

Article 2 provides that the Uniform Act on Mediation shall apply to mediation. The territorial jurisdiction relating to the application of the Uniform Act has not been precised. It is worth noting that it will regulate all mediation procedures arising within the OHADA member States. Regarding the personal jurisdiction, the uniform act will regulate disputes arising out of a legal or contractual relationship involving natural persons or legal entities including public bodies or States [11]. With regards the material jurisdiction, it applies to disputes arising from commercial matters within the OHADA Zone. It does not apply to family disputes or succession disputes [12].

\section{The Mediator}

Once the mediation is accepted, the parties will be able to choose freely and by mutual agreement a third party mediator, independent, impartial and free from any conflict of interest, natural or legal person without distinction of nationality and or to be assisted in appointing the mediator by an appointing authority [13]. By virtue of Article 5 of the Uniform Act on Mediation, the mediator is chosen by the parties in one accord. It is a principle which applies equally to matters of arbitration. The will of the parties sets in motion the mediation process. It should be noted that the possibility of appointing several mediators as provided for in this same article makes an implied reference to co-mediation which can involve private entities and public entities at the same time [14]. 
For the designation of the mediators, the parties may request assistance from any natural or legal entity, in particular a center or an institution offering mediation services, named the "appointing authority". For this purpose, one party may request the appointing authority to recommend persons with the required qualities and skills to serve as mediator. The parties may also agree that the appointing authority directly appoints the mediator or mediators directly [15]. In this case, the reformers did not foresee any restrictions on the status of the "appointing authority." They only specify that it may be a center or an institution offering mediation services for instance the Ouagadougou Arbitration, Mediation and Conciliation Center or the Conciliation and Arbitration Center of Mali. An "appointing authority" could therefore be a mediation center located in a non-OHADA State.

In order to recommend or appoint mediators, the appointing authority shall take into account the considerations which will ensure the designation of an independent, impartial and available person. It shall take into account, if applicable, the fact that it may be desirable to appoint a person of a different nationality from that of the parties, in particular when the parties are of different nationalities [16].

When a person is contacted to be designated as a mediator, she must report any circumstances likely to raise legitimate doubts about her impartiality or independence. As of her appointment and during the whole mediation process, the mediator must reveal without delay to the parties any new circumstances likely to raise legitimate doubts about their impartiality or independence.

\section{Status of a mediator under OHADA Law}

At the time of her appointment, the mediator shall confirm in writing her independence and impartiality, as well as her availability to carry out the mediation process. In the event that the mediator reveals to the parties after her appointment the occurrence of new circumstances likely to raise legitimate doubts about her impartiality or independence, she shall inform them of their right to object to pursue her mission. In the event that one of the parties consequently refuses to pursue the mediation, the mediator's mandate is ended [17]. The mediator is not a judge. Its role is to help the parties, whether assisted or not by their lawyer find a solution to their dispute in accordance with public order from the exchanges and information collected without imposing their solution [18].

\section{Mediation procedure under ohada law}

The mediation procedure shall start on the date when the most diligent party implements a written or oral mediation agreement. If in the absence of an agreement, the party which invited the other party to mediation has not received acceptance of its written invitation within 15 days of the date of reception of the invitation, or on the expiry of any other dateline specified therein, it may consider the absence of a response as a rejection or the invitation to mediation [19].

The mediator and any mediation center established in a member state must adhere to the principles guaranteeing the respect of the will of the parties, the moral integrity, the independence and impartiality of the mediator, the confidentiality and the effectiveness of the mediation process [20]. The parties are free to agree including by reference to the rules of a mediation center, on the manner in which the mediation is to be conducted, contrarily to the rules of the centers which provide for the procedure to be followed. In addition, the Uniform Act on Mediation provides for the suspension of time-limit for an action initiated before a State Court or arbitral tribunal, in order to allow the parties to resort to mediation. If the parties reach an agreement, they may withdraw from the original proceedings or if not continue the procedure. In general, the mediator performs his or her duties diligently and in the conduct of the mediation, gives fair treatment to the parties taking into account the circumstances of the case. The information provided during the mediation proceedings is confidential and may only be disclosed in the cases provided for by the law or for the purposes of implementing or enforcing the agreement resulting from mediation [21].

\section{Mediation costs under OHADA Law}

The parties shall determine, either directly, or by reference to Rules of mediation, the costs of the mediation, including the mediator's fees. In case of a judicial mediation, the relevant state court, which appoints a mediator, shall fix the costs in agreement with the parties, and shall order the payment of advances on costs to the head clerk of the court or the competent body for the Member State. When a party fails to pay its share of the costs, the other party may pay this advance to allow the mediation to start. Where there is absent of any payment by the parties of their advances within the time limit set by the judge, its decision to refer to mediation shall be void, and legal proceedings shall be re initiated to normal. When the state court appoints a mediation institution, it shall invite the parties to comply with the schedule of fees of this institution. The fees of the mediation shall be borne by the parties in equal shares, unless otherwise agreed [22].

\section{The End of the Mediation Proceedings}

After various exchanges and receipt of the report of expertise recommended by the mediator if need be, the mediation ends in the best case by a written agreement signed by all the parties and by the mediator if the parties so wish. This agreement will have the value of the agreed matter, that is to say that it will 
produce effects only between parties as a new contract which obliges them [23].

In order to guarantee the compulsory execution of the mediation agreement and to confer on it the authority of the matter transacted, the Uniform Act on Mediation provides that the parties will have [24] a choice between the submission of the agreement in the minutes of a notary public for the authentication of writings and signatures and issuance of an enforceable copy or the request for the approval of the agreement/exequatur before the competent state jurisdiction.

The homologation order is issued by the judge, after verifying the authenticity of the mediation agreement and its compliance with public order within a maximum deadline of 15 working days from the date of the filing of the request otherwise the homologation or exequatur is deemed to have been acquired (automatic homologation).

It should be noted that, the rules of certain centers such as the CACI do not send parties back to the State judge so that the latter confers on the agreement the authority of res judicata with compulsory execution. In our view, such an absence of a referral to a State judge does not alert the parties on the necessity to require the opposition of the executory formula on their agreement in order to avail them of any right deriving there from. Hence this precision being made under the present Uniform Act on Mediation is, therefore, recommendable on this point [25].

Finally, it should be noted that the parties have two forms of appeals, namely (i) an appeal against the Automatic Homologation before the Common Court of Justice and Arbitration (CCJA) if one of the parties considers that the agreement to mediation is not in compliance with public policy and (ii) an appeal before the CCJA in case of refusal of the homologation or the exequatur by the judge [26]. The decision of the judge granting homologation or exequatur is not subject to any appeal. The rules of the mediation centers do not provide for the execution procedure of the agreements reached between the parties who must go before the court of competent jurisdiction to have the executory formula apposed on such agreements. In case of an appeal against the mediation agreement, the parties are subject to the rules of ordinary law [27].

\section{CONCLUSION AND THE WAYFORWARD}

While the Uniform Act on Mediation was inspired by the 2002 UNCITRAL Model Law on ICC and takes into account benchmarks of International best practices, it has adopted innovative provisions for the enforcement of settlement agreements within OHADA. This is likely to encourage parties to settle their disputes through mediation. The successful implementation of the new Uniform Act on Mediation will depend on the efforts of each OHADA Member State to develop the practice of mediation. For example, by encouraging judges to send litigants, whenever appropriate before the mediator and by making enterprises whether from the private or public sector aware of the advantages of mediation. The successful implantation will also require the training of an increasing number of qualified mediators and the development of institutions providing both mediation and arbitration services.

On the regional level, this task will be challenging since no single institution provides mediation services for the entire OHADA region. As the arbitration center of the CCJA has no mediation rules as such, those engaging in cross-border business transactions in the OHADA region are likely to continue to prefer recourse to national or international institutions that offer both mediation and arbitration services such as the International Chamber of Commerce.

Member States should give themselves the means to make mediation an effective tool towards improving the conditions of access to justice. Through awareness campaigns in association with legal professionals, control the costs so that it remains accessible to all, and training sessions, mediation in the member states could be pivotal in enhancing justice and improving the business environment in the OHADA area, as with the training offered within OHADA's ERSUMA.

\section{REFERENCES}

1. Betrand, D., \& Astrid, D.F. (2018). "The New Mediation in Ohada Space for better access to justice," La Tribune d'Afrique.

2. Ibid.

3. Ibid.

4. Chazai., \& Partners. (2018). "Focus on Mediation: The Major Innovation of OHADA Law concerning Amicable Settlement of Disputes," 3.

5. See Article 1 of the New Uniform Act on Mediation.

6. Henri, T. (1977). "Propositions visant à Ameliorerl'efficacite de la Mediation dans les Conflits du travail," Droit Social, 87.

7. Arnaud, A.J. (1986). "Dictionnaire Encyclopedique de Theorie et de Sociologie du Droit," 13.

8. See Article 1(b) of the Uniform Act on Mediation.

9. Ibid.

10. Chazai, \& Partners. (2018). "Focus on Mediation: The Major Innovation of OHADA Law concerning Amicable Settlement of Disputes," 2.

11. See Article 1(a) of the Uniform Act on Mediation.

12. Micheal, W.B., \& Anne, S.G. (2018). "Le 10eme Acte Uniforme de l'OHADA sur Mediation," Lexbase Edition OHADA, 13(3).

13. Betrand, D., \& Astrid, D.F. (2018). "The New Mediation in Ohada Space for better access to justice," La Tribune d'Afrique. 
14. Micheal, W.B. \& Anne, S.G. (2018). "Le 10eme Acte Uniforme de l'OHADA sur Mediation," Lexbase Edition OHADA, 3, 4.

15. See Article 5 of the Uniform Act on Mediation.

16. Yvette, R.K.E. (2018). "Acte Uniforme OHADA Relatif a la Mediation; L'essentiel à retenir," Actualite Juridique, Droit OHADA.

17. Ibid.

18. Betrand, D. \& Astrid, D.F. (2018). "The New Mediation in Ohada Space for better access to justice," La Tribune d'Afrique.

19. See Article 4 of the Uniform Act on Mediation.

20. See Article 8 of the Uniform Act on Mediation.
21. See Article 10 of the new Uniform Act on Mediation.

22. See Article 13 of the Uniform Act on Mediation.

23. Yvette, R.K.E. (2018). "Acte Uniforme OHADA Relatif a la Mediation; L'essentiel à retenir," Actualite Juridique, Droit OHADA.

24. See Article 16 of the New Uniform Act on Mediation.

25. Chazai., \& Partners. (2018). "Focus on Mediation: The Major Innovation of OHADA Law concerning Amicable Settlement of Disputes," 6.

26. Ferreon, A. le projet de loi.

27. Ibid. 